male counterparts or women, whether married or single, who do not have children. Thus, Xie and Shauman believe that the gender gap in parenting responsibilities is a barrier to women's progress in science careers.

They offer few policy recommendations, but at least one seems new. Given the likelihood that a woman who leaves college with a science or engineering degree began her studies in a non-science field, educators need to figure out how to make studying science more attractive to women who are currently majoring in something else. Recruitment at the undergraduate level may be at least as important as retention.

Xie and Shauman's findings also provide further evidence for the idea that employers should embrace policies that increase both flexibility (such as job-sharing and flexitime) and the availability of on-site childcare for working mothers.

It is important to note that the methodology that enables Xie and Shauman to provide us with definitive answers to some kinds of questions is a blunt instrument when it comes to others. For example, the authors are explicitly unable to address any possible school-level influences on young women's career plans, and cannot distinguish between physics, which currently attracts few women, and the biological sciences, in which women earn as many or more degrees than men. Nor can they offer insight into questions of institutional climate and practice and their effects, including effects on post-undergraduate leakage from science.

This is not to disparage the book for what it does not do - Xie and Shauman's careful research answers hard questions that have, in the past, seemed virtually unanswerable but simply to note the limitations inherent in using the kind of data available to them. Their work should serve as a stimulus to further research applying equally careful and creative approaches to the many questions that remain.

Abigail J. Stewart is in the Department of Psychology and the Program in Women's Studies, and Danielle LaVaque-Manty is at the Institute for Research on Women and Gender, University of Michigan, Ann Arbor, Michigan 48109-1109, USA.

\section{The descent of man}

\section{Adam's Curse: A Future \\ Without Men}

by Bryan Sykes

Bantam Press: 2003. 300 pp. $£ 18.99$

\section{Jennifer A. Marshall Graves}

I think 2003 must have been the Year of the Sex Chromosomes. On the heels of Steve Jones' $Y$ and David Bainbridge's The $X$ in Sex (both reviewed in Nature 423, 223; 2003) comes Adam's Curse: A Future Without

\title{
Wildlife in watercolours
}

The German artist and natural historian Maria Sibylla Merian (1647-1717) was a remarkable woman who, as a single mother, earned her living as an artist and travelled to South America in search of new specimens to paint. She came from a family of artists her father was an engraver, and both her stepfather and her husband were painters.

Maria had a keen eye for nature and as a child kept silkworms so that she could record their development in her paintings of flowers and insects.

She published many books of her own, although the painting of coconut crabs shown here was one of the illustrations she made for Georg Eberhard Rumpf's book D'Amboinsche Rariteitkammer.

Many of Maria's original paintings were purchased by Tsar Peter the Great for his art museum in St Petersburg, Russia. They are now available to a wider audience in Maria Sibylla Merian: The St Petersburg Watercolours (Prestel, £55).

Mary Purton

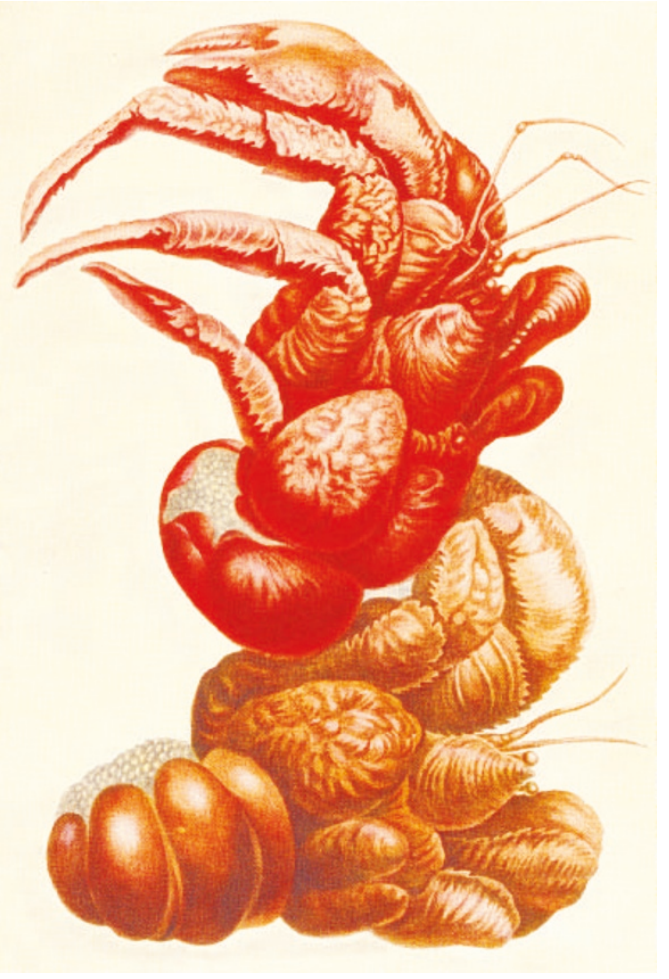

Men (note the absence of a question mark).

After reading Bryan Sykes' delightful article on the history of the Sykes Y chromosome (Am. J. Hum. Genet. 66, 1417-1419; 2000) and his successful book The Seven Daughters of Eve (Norton, 2001), I looked forward to this book. I admire authors who can interest non-scientists in genetics - a vital skill if we are to cultivate an informed public to debate the manipulation of sex and reproduction.

Indeed, the book is fun to read - the writing style is lively, the images fresh and witty, the explanations of basic genetic principles apt and accurate, even inspired. Like $Y$, Adam's Curse centres on sexual conflict, here the war between the mother's mitochondrial genome and the father's Y chromosome. Sykes traces the spread of the Y chromosome in space and time, enriching the account with the history of Vikings, Polynesians and Genghis Khan.

The author's focus on his own family is a good device to explain how the Y chromosome gets around and to introduce the history of families and surnames, migrations and conquests. But the focus on Sykes and his family, Sykes' blood cells and the Sykes Y chromosome, then Sykes' ideas and finally Sykes' wild speculations, rather gives the impression that the entire field was explored single-handedly by Bryan Sykes, genetic supersleuth.

Of particular interest to me were the dire predictions of the imminent decay of the Y chromosome. Sykes calculates from the frequency of $\mathrm{Y}$ mutations in men (can it really be high as $2 \%$ ?) that the fertility of the whole human population will plummet within 125,000 years (upping the ante on my calculation of 9 million years). But does the disappearance of the $\mathrm{Y}$ chromosome, as Sykes avers, really mean the extinction of humankind unless we can dispense with the imprinting of at least 100 genes and embrace parthenogenesis? I don't see why. After all, several spermatogenesis genes, and even $S R Y$, have already been dumped in other species with no ill effect.

Indeed, the book abounds with bold assertions hedged by "I can't prove it but...". Families that produce more boys than girls (the Sykes clan again, documented by dusty records from a village school) expose a superselfish Y chromosome. Newspaper accounts of female-only families are proof of toxic, Y-hating, superselfish mitochondria. Even the 'gay gene' turns out to be a mitochondrial plot.

I welcome speculation in popular-science books. Sharing with the public the leaps of imagination that make science exciting and creative might banish its image as gadget-driven and boffin-dominated. But speculation on speculation becomes tedious, and ultimately I feel that the central argument degenerates under its weight - like the Y chromosome itself.

Jennifer A. Marshall Graves is in the Research School of Biological Sciences, Australian National University, Canberra, ACT 2601, Australia. 